\title{
Online Shopping In The UK
}

K. K. Ramachandran, GRD Institute of Management, India

K. K. Karthick, PMR Institute of Management, India

M. Saravana Kumar, Anna University, Coimbatore, India

\begin{abstract}
This paper will contribute to current academic literature in the area of online retailing and consumer behaviour. Our research outlines a survey conducted with respondents from the UK to ascertain their attitudes to grocery shopping both off and online. The findings indicate that, whilst the vast majority of our sample has experience of online shopping, few actively engage in online grocery shopping. Some of the reasons for this are highlighted and the key issues relate to consumer trust and confidence in both online and offline aspects of the service. If these issues are addressed, it is proposed that more people would be encouraged to shop for groceries online.
\end{abstract}

Keywords: Online Retailing; Shopping Motivation; Buying Behaviour; Electronic Commerce

\section{INTRODUCTION}

C)

ince the turn of the new millennium, e commerce technologies and methods have had a radical impact on the way businesses operate. Online trading has been adopted by numerous British companies and according to the DTI in 2000 as many as $27 \%$ of UK businesses have already traded online. The Office for National Statistics (2002) conducted an e-commerce survey with 12,000 businesses of all sizes across most of the economy, the results of which showed that online sales to households had increased by $53 \%$ from £4bn to $£ 6.1 \mathrm{bn}$ compared to 2000. According to BBC News (2009) online shopping is bucking the downward trend on the UK High Street, as latest figures show the "e-tail" sector made a $13 \%$ annual sales increase in February. Based on nonseasonally adjusted data, the average weekly value of internet retail sales in December 2008, as a percentage of total retail sales, increased by 19.6 per cent compared with a year earlier. Internet sales now $3.4 \%$ of all retail trade with the UK's online retailers generated sales of $£ 167 \mathrm{~m}$ per week in February 2009, according to the UK Office for National Statistics.

There are many reasons for doing business electronically. The Office for National Statistics (2002) suggests that "[e-commerce] has the potential to lead to growth in trade, increase markets, improve efficiency and effectiveness and transform business processes." In addition, the DTI (2005) claims that both customers and suppliers can benefit from online trading, because it often promises "greater market penetration, increased customer response, more flexibility and lower costs."

Despite this growth, many researchers (Rohm and Swaminathan, 2004; TEO, 2002; Lokken et al., 2003 and George, 2004) have concluded that the potential for massive growth in e-commerce is yet to be realised and that the majority of internet users may search information via the Web but still shop offline. How to transform information seekers to online buyers is a critical issue for organisations, since it is becoming one of the fundamental benchmarks for success in today's fierce competitive business environment. Helander and Khalid (2000, cited in Konradt et al. 2003, p.165) have stated that "for commercial web sites, it is important not only to attract as many users as possible to visit their sites, but not to lose them and make them customers as well." Studies about online consumer purchasing behaviour are needed to help companies perfect all aspects of their online retail strategies (Lohse et al., 1999 cited in Teo, 2002). It has long been contended that "understanding and adapting to consumer motivation and behaviour is not an option - it is an absolute necessity for competitive survival." (Engel, Blackwell and Miniard, 1995, p.12) Given the rising importance of online retailing, retailers need to understand and respond to the motivations that drive consumers to shop online. 
While online shopping and online shopping behaviour in general are comprehensively researched (Burnett and McCollough, 1994; Rowley, 1996; Alba et al. 1997; Childers et al. 2001, Blake, Neuendorf and Valdiserri, 2003; Baltas and Papastathopoulou, 2003; Yang and Lester, 2004; Barlow, Siddiqui and Mannion, 2004 and Joia and Sanz, 2005; Farag, Krizek and Dijst 2006; Farag, Schwanen, Dijst and Faber 2207; Weltereden and Van Rietbergen 2009) the research focusing on online grocery shopping specifically is more sporadic. Delivery of groceries has been a niche market in the past, with the milkman and ready-to-eat meals (take-away delivery) being traditional examples. With the advent of online shopping there is unexploited potential for growth which could revolutionize the grocery industry. The investment of large supermarket chains, e.g. Tescos, Sainsbury's and the development of new partnerships in this area, such as Ocado, highlight the growing commercial awareness of this potential.

For most customers, grocery shopping is a routine activity repeated at regular and frequent time intervals and often involves a wide array of products (Raijas and Tuunainen, 2001; Rohm and Swaminathan, 2004; Wasserman 2009). The British food retailing industry has reached a mature stage, where low profit margins and limited growth space indicate fierce competition. This competition in grocery retailing requires organizations to seek strategies to retain customers; to explore improvements in service, products, and the quality of web sites. (Rohm and Swaminathan, 2004)

The economic importance of grocery shopping coupled with the evidence regarding competition for customers between online and offline channels makes an exploration into motivations and attitudes of both online and offline grocery consumers particularly pertinent.

Our research aims to add to the body of the research in this area by exploring further the insights into grocery purchasing attitudes and behavior. This may inform future online retail strategy in terms of improving understanding of customer priorities.

\section{RESEARCH CONTEXT}

Our research is informed by previous studies into shopping behaviour, motivation, and buying intention from a range of retail contexts. The research focuses on shopping motivations (Westbrook and Black, 1985; Rohm and Swaminathan, 2004), consumers' attitudes toward the Internet and online shopping (Teo, 2002, 2006), perceived benefits of online shopping (Lokken et al., 2003, Rucai 2009), reasons for online grocery shopping (Morganosky and Cude, 2000; Hansen, Jensen, and Solgaard, 2004; Weltereden and Van Rietbergen 2009), and factors affecting consumer purchase behavior (Park and Kim, 2003; Gehrt and Yan, 2004). The research can be categorized according to the following themes:

\section{Consumers' experiences and attitudes towards offline (traditional) shopping}

According to Rohm and Swaminathan (2004), time saving and recreational motives were significant motivations in the offline shopping context. Westbrook and Black (1985) and Lokken et al. (2003) also indicated that a high percentage of non-online shoppers enjoy the experience of shopping at brick-and-mortar stores. The study by Morganosky and Cude (2000), which focused on groceries specifically, only reported a small minority of respondents who hated shopping in grocery stores.

\section{Reasons for purchasing online}

Lokken et al. (2003, p.130) found "convenience, [gaining] other shoppers' opinions, vendor information availability and lack of sales pressure" as the perceived benefits of online shopping. Park and Kim (2003) discovered that consumers' commitment to an online store is related to the extent to which their information needs are satisfied. $\mathrm{Te} 0$ (206) found that consumers liked the provision of more information about the products that they were buying.

In the grocery shopping context, convenience and saving time were reported by Morganosky and Cude (2000) as key motivators for purchasing groceries online. (Weltereden and Van Rietbergen 2009) found that the 
convenience of not going to city centres was an important convenience factor. Rohm and Swaminathan (2004) established that key motivating influences would vary according to shopper personality "type". There were shoppers who belonged to the 'convenience shopper' category but others who were 'variety seekers' and more motivated by the desire to seek choice and variety in products, prices etc. Westbrook and Black's (1985) categorization of shoppers identified similar differences in motivation. 'Shopping process involved' shoppers are those who are actively involved and interested in the process of shopping and may be more likely to be interested in variety, as opposed to those who are 'shopping process apathetic' and more likely to be driven by what is most convenient.

\section{Disadvantages of online shopping}

Many authors cite security as a key factor in make consumers vary of internet purchases. According to Teo (2002) and Lokken et al. (2003), security issues and the perceived risks associated with purchasing online are primary barriers to online shopping. Gupta, Handa, and Gupta (2008) from their study, found young Indian adults do not trust online shopping. Martin, Camarero, Hernandez and Vallis (2009) found that risk was a key element in deterring Spanish online shoppers. Teo (2002) found that other common reasons for not purchasing online were the preference to examine products, [also cited by Gupta, Handa, and Gupta (2008)], concern over costs of internet access and internet response time and generally finding browsing tiresome. In terms of shopping for groceries, inadequate food product descriptions and information, website technical problems, information layout and extra charges are listed by Morganosky and Cude (2000) as the main pitfalls.

\section{Factors to encourage online shopping}

Rohm and Swaminathan (2004) suggested that improvements in delivery service, e.g. same-day delivery, were needed to increase the likelihood of online grocery shopping. Lokken et al. (2003) suggested that improvements in credit card security and providing opportunities for customers to compare products across different catalogues (improvements in information) would encourage online shopping. Teo (2002) asserted that security and trust issues are the most fundamental factors that need to be addressed in order to encourage growth in online shopping.

The findings from the studies outlined above, all of which were conducted outside of the UK, provided the direction for this survey and the basis upon which questions were developed to explore UK consumer attitudes towards online shopping for groceries (referred to as OGS from now on).

The survey questions are based upon the following themes:

$1 \quad$ What are grocery shoppers' experiences and attitudes towards offline grocery shopping?

$2 \quad$ What are the benefits and what are the drawbacks of OGS?

$3 \quad$ How could OGS be improved? What factors increase the likelihood of OGS?

\section{METHODOLOGY}

\subsection{Participants}

The population for this study included students and working professionals from UK. The sampling method is non-probability or purposive sampling. Although 'convenience' sampling is sometimes motivated by mere accessibility, an added value can be that it allows selection of participants who share certain desired characteristics (Riley et al, 2000).

Our sample was selected in order to maximize the possibility of choosing respondents who are familiar with the use of the Internet but not necessarily experts in IT, who are likely to be responsible for regular grocery shopping. This enables our study to be more targeted on the group of consumers who have a higher probability of shopping for groceries online and therefore to find out more about the motivations and attitude barriers for and against OGS. 


\subsection{Questionnaire Design}

The questionnaire was designed with predominantly closed questions in order to enhance comparability of answers within our sample and between ours and others' research. (Blaxter, Hughes \& Tight, 1996; Bryman \& Bell, 2003).

A five point Likert scale with a horizontal format was used, to enable pre-coded replies for the sections relating to attitudes and opinions.

Some of our questions were based on existing questions from previous research, particularly Rohm and Swaminathan (2004), Lokken (2003) and Teo (2002), the latter who included details of The Sunday Times (1999) survey, upon which their results were based. As stated in Bryman \& Bell (2003), using existing questions allows us to indicate the nature of changes in direct comparison with previous research.

\subsection{Data collection procedure}

Our survey took the form of a self-administered online questionnaire. There were several reasons for using a self-administered online questionnaire. Questionnaires are especially good at collecting information on facts and opinions from a large number of people and are more versatile than most techniques, despite having less qualitative depth than some alternatives (Clark et al. 1998). Self-administered online questionnaires particularly, are time and cost efficient. The answers from web questionnaires are inherently machine-readable, can be stored in a database and converted into a format readable by a statistics package (in this case SPSS) which eliminates the chance of incorrectly transcribing respondents' answers. Another benefit of the web based survey may be in improving accessibility to people of varying disability. In this survey, JAWs (Job Access for Windows), a screen reader tool to aid disabled users of PCs, was available for a Web version of the questionnaire.

The Web questionnaire was tested in different browsers prior to sending out the emails as different browsers interpret the same HTML code in subtly different ways (Fraley, 2004). Keeping track of the movements of visitors on the web questionnaire and distinguishing between concurrent visitors were problems solved by assigning a randomly generated unique code to every web visitor.

A pilot was conducted before the questionnaire was sent out. It was conducted with 10 respondents and helped in refining the questions and the layout of the questionnaire. On the basis of the pilot results, the scale was reversed to prevent a tendency to report automatic agreement to statements posed.

The survey was sent out via email, attaching a self-administered Microsoft Word version of the questionnaire with designed forms and data protection function and a hyperlink directed to the self-administrated online questionnaire.

A covering letter was included with the questionnaire to explain the purpose of the research and give our assurance of confidentiality and anonymity (Bryman \& Bell, 2003). In order to avoid one of the pitfalls of email surveys which is lack of authoritative image, (Ranchhod \& Zhou, 2001), the email letters were signed with the researchers' names, positions, and contacts.

The replies collected from the web questionnaire were stored in a MySQL database and then imported into SPSS in order to statistically analyze the data. The answers collected from the Word documents via emails were entered into SPSS manually.

\subsection{Analysis Method}

The analysis is based on Principal Component Analysis. The main purpose of Principal Component Analysis is data reduction, which makes it possible to explore complex relationships underlying each variable, look at the underlying reasons for the respondents' answers and identify common themes in the factors extracted (Hair et al.,1998). Our aim is to explore the underlying reasons and motivations for OGS and its perceived disadvantages. 
The data was screened by analyzing the correlation matrix of all variables to look at the inter-correlation between variables, to ensure the variables were sensible and the taxonomy would have a real meaning. The sampling adequacy and the overall significance of all correlations were ensured by using the Kaiser-Meyer-Olkin measure and Bartlett's test of sphericity. Only factors with factor loading higher than .57 were considered for components discovered during the analysis. Given our number of respondents, according to the guidelines for identifying significant factor loadings (Hair et al., 1998), the findings from this analysis are statistically significant.

These key factors or components are related to common areas of agreement or disagreement within our survey sample, based on comparisons of frequency of responses to each item in turn.

\section{RESULTS}

The questionnaire was sent out to 11706 people. We received 261 completed questionnaires with valid answers (response rate $=2.23 \%$ )

The response rate for mailed surveys, sent anonymously, is notoriously low (Byrne 2002, Bryman \& Bell 2003, Riley et al. 2000, and Blaxter, Hughes \& Tight 1996). However in non-probability sampling this is not an issue that affects the validity of the sample, which is already self- selected. (Bryman \& Bell 2003)

\subsection{Demographics}

Table 1 lists the respondent demographic profile. The majority of the respondents are female, under 25 years of age, educated to 'A' level standard and earning below $£ 15,000$.

Table 1: Respondent demographic profile

\begin{tabular}{|c|c|}
\hline Demographics & Respondents (\%) \\
\hline \multicolumn{2}{|l|}{ Gender } \\
\hline Male & 23.9 \\
\hline Female & 76.1 \\
\hline \multicolumn{2}{|l|}{ Age (years) } \\
\hline Under 25 & 62.0 \\
\hline $26-35$ & 17.0 \\
\hline $36-45$ & 11.4 \\
\hline $46-55$ & 7.0 \\
\hline Over 55 & 2.6 \\
\hline \multicolumn{2}{|l|}{ Current occupation } \\
\hline Full-time education & 64.4 \\
\hline Part-time education & 7.7 \\
\hline Full-time employment & 14.9 \\
\hline Part-time employment & 13.0 \\
\hline Work from home & 3.1 \\
\hline \multicolumn{2}{|l|}{ Education } \\
\hline GCSE / O-Levels & 53.6 \\
\hline A - Levels & 48.3 \\
\hline NVQ & 9.2 \\
\hline Undergraduate degree & 31.4 \\
\hline Postgraduate degree & 11.1 \\
\hline \multicolumn{2}{|l|}{ Household gross income } \\
\hline Below $£ 15,000$ & 39.3 \\
\hline$£ 15,001$ to $£ 25,000$ & 18.2 \\
\hline$£ 25,001$ to $£ 35,000$ & 19.2 \\
\hline$£ 35,001$ to $£ 45,000$ & 10.7 \\
\hline$£ 45,001$ to $£ 55,000$ & 4.7 \\
\hline$£ 55,001$ and over & 7.9 \\
\hline
\end{tabular}


Table 2 details the demographic profile between online and traditional (offline) grocery shoppers. [Online shoppers are defined here as those who have attempted online grocery shopping at least once, offline grocery shoppers as those who have never attempted it at all.]

Table 2: Respondent demographic profile- online or offline shoppers *

\begin{tabular}{|c|c|c|}
\hline Demographics profile & Online shoppers (\%) & Offline shoppers (\%) \\
\hline \multicolumn{3}{|l|}{ Gender } \\
\hline Male & 24.5 & 75.5 \\
\hline Female & 31.0 & 69.0 \\
\hline \multicolumn{3}{|l|}{ Age (years) } \\
\hline Under 25 & 23.4 & 76.6 \\
\hline $26-35$ & 28.9 & 71.1 \\
\hline $36-45$ & 57.7 & 42.3 \\
\hline $46-55$ & 37.5 & 62.5 \\
\hline Over 55 & 20.0 & 80.0 \\
\hline \multicolumn{3}{|l|}{ Current occupation } \\
\hline Full-time education & 28.1 & 71.9 \\
\hline Part-time education & 35.0 & 65.0 \\
\hline Full-time employment & 33.3 & 66.7 \\
\hline Part-time employment & 29.4 & 70.6 \\
\hline Work from home & 37.5 & 62.5 \\
\hline \multicolumn{3}{|l|}{ Education } \\
\hline GCSE / O-Levels & 26.6 & 73.4 \\
\hline A - Levels & 24.0 & 76.0 \\
\hline NVQ & 29.2 & 70.8 \\
\hline Undergraduate degree & 26.8 & 73.2 \\
\hline Postgraduate degree & 41.4 & 58.6 \\
\hline \multicolumn{3}{|l|}{ Household gross income } \\
\hline Below $£ 15,000$ & 23.8 & 76.2 \\
\hline$£ 15,001$ to $£ 25,000$ & 15.4 & 84.6 \\
\hline$£ 25,001$ to $£ 35,000$ & 32.5 & 67.5 \\
\hline$£ 35,001$ to $£ 45,000$ & 34.8 & 62.5 \\
\hline$£ 45,001$ to $£ 55,000$ & 60.0 & 40.0 \\
\hline$£ 55,001$ and over & 47.1 & 52.9 \\
\hline
\end{tabular}

* Online shoppers are defined as those who have attempted online grocery shopping at least once, offline grocery shoppers as those who have never attempted it at all.

A higher percentage of female grocery shoppers engaged in OGS compared to the male respondents. This is consistent with the findings from Morganosky and Cude (2000), BBC News (2002), Park and Kim (2003), Lokken et al.'s (2003), Armitt (2004), and Rohm and Swaminathan's (2004) and Sebastianelli, Tamimi and Rajan (2008).

The results also indicate that people who are in their 30s and 40s, with higher educational background and higher income engage in more OGS than in other categories. This is also consistent with previous on line shopping research; Morganosky and Cude (2000), Lokken (2003) and Rohm and Swaminathan (2004).

\subsection{Internet use}

In our survey $100 \%$ of respondents who gave valid answers use the Internet.

$79.2 \%$ of the respondents have done online shopping whilst only $36.8 \%$ of the respondents have done online grocery shopping, and only $21.0 \%$ within the last six months.

While $86.5 \%$ of the respondents were confident in using the Internet, the majority of the respondents (73.3\%) still preferred to shop for groceries purely offline. 
These findings imply that Web inexperience does not appear to be the key issue for people who took part in our survey.

The tables that follow highlight the predominant themes identified during Principal Component Analysis. where the factor loading is greater than .57 .

\subsection{Consumers' experiences and attitudes relating to traditional (offline) grocery shopping} Table 3).

The analysis showed that a three component solution (loading value no less than .609) was selected (see

Table 3. Consumers' experiences and attitudes relating to traditional (offline) grocery shopping (Principal component analysis report)

\begin{tabular}{|c|c|c|c|}
\hline \multirow{2}{*}{ Question } & \multicolumn{3}{|c|}{ Component } \\
\hline & 1 & 2 & 3 \\
\hline 9. I enjoy grocery shopping & .719 & & \\
\hline 10. I go grocery shopping even when I am unsure what I need & 676 & & \\
\hline 1. I often buy things that I didn't plan to buy during my grocery shopping & 613 & & \\
\hline 6. I go to different shops to compare prices and products & & .721 & \\
\hline 7. I often ask shop assistants to give me suitable advice & & 697 & \\
\hline 8. I like to feel and touch the products before I purchase them & & .653 & \\
\hline 2. It's important for me to get the goods straight away after my shopping & & & .823 \\
\hline 3. I go to the nearest shops for my weekly grocery shopping & & & .609 \\
\hline
\end{tabular}

Component one has the highest component loading on question one, nine, and ten. The underlying theme relating these questions seems to be about shopping spontaneity and has characteristics in common with the "recreational shopper" cited by Westbrook and Black (1985).

The second component relates to question six, seven, and eight and highlights a theme about finding the right product. A possible label for this component could be "choice optimising", again relating to the findings of Westbrook and Black (1985) or, "variety seeking" as identified by Rohm and Swaminathan (2004).

The third component has the highest loading from the variables generated by question two and three. A suitable label for this component could be "functional shopping" (Rohm and Swaminathan, 2004) or, as is defined here, "shopping-process apathetic" behaviour, in accordance with Westbrook and Black (1985).

The majority of our respondents belonged to categories defined by components 1 and 3 and demonstrated behaviour that could be considered spontaneous and also motivated by convenience. There was no strong response for the items related to the choice optimising theme (see Table 3b, Appendix A).

\subsection{Reasons for purchasing groceries online}

There are three components (loading no less than .659) identified (see Table 4).

The first component has the highest component loading on questions three to six and may highlight the underlying motivation of "choice optimisation" (Westbrook and Black, 1985) or "variety seeking" (Rohm and Swaminathan, 2004).

Question eight and eleven are related in the second component for OGS adoption, the proposed theme for which is "shopping-process apathetic" (Westbrook and Black, 1985). As the items are referring to reasons of efficiency, an appropriate description of the underlying motive may also be convenience. 
Table 4. Reasons and motivations for purchasing groceries online (Principal component analysis report)

\begin{tabular}{l|c}
\hline Question (Grocery shopping on-line enables me to: ...) & Component \\
\hline $5 . \quad \ldots$ choose from a wider selection & $\mathbf{1}$ \\
$6 . \quad \ldots$ have the latest products and services & .789 \\
$4 . \quad \ldots$ be on the leading edge of technology & .781 \\
$3 . \quad \ldots$ get better prices & .682 \\
\hline $8 . \quad \ldots$ save time & .659 \\
$11 . \ldots$ make less effort in doing shopping & $\mathbf{3 4 0}$ \\
\hline $2 . \quad \ldots$ order groceries from distant places & .797 \\
$1 . \quad \ldots$ buy groceries at any time & .788 \\
$7 . \quad \ldots$ do shopping anywhere as far as I can access the Internet & .783 \\
\hline
\end{tabular}

(Component 1: choice optimisation/ variety seeking; Component 2: shoppuing process apathetic/ convenience; Component 3: Convenience)

Component three has the highest loading on question one, two, and seven. The theme highlighted by this component may also be identified in terms of convenience; the convenience of being able to shop from anywhere, to anywhere, any time.

Many of the respondents showed strong agreement with items in components 2 and 3 (see Table 4b, Appendix A). This is consistent with the findings from Morganosky and Cude (2000), Gomez, Inc. (2001), Lokken et al. (2003), and Rohm and Swaninathan (2004), and Teo (2006), that convenience is a fundamental motivation for adopting OGS. Where additional comments were made, many mentioned the convenience of not being constrained by time, distance and place. There was not a high percentage of agreement with items in component one. This is consistent with the respondents' behaviour offline and indicates that, within our sample, choice optimisation and variety seeking are not key motivators when grocery shopping.

\subsection{Disadvantages of OGS}

Four critical factors (loadings are no less than .593) are identified in the context of the disadvantages of OGS (see Table 5).

Table 5. Disadvantages of OGS (principal component analysis report)

\begin{tabular}{|c|c|c|c|c|}
\hline \multirow{2}{*}{ Question } & \multicolumn{4}{|c|}{ Component } \\
\hline & 1 & 2 & 3 & 4 \\
\hline 16. Products purchased online are not as good as described on the Web & 680 & & & \\
\hline 14. I don't have time to search information from the Web & .663 & & & \\
\hline 7. It takes too long to complete the purchase & 637 & & & \\
\hline 15. I can't buy the range of products I want online & 632 & & & \\
\hline 3. The sites are not easy to look through & .593 & & & \\
\hline 5. The products are not well described & & .719 & & \\
\hline 4. I cannot try out the products & & .704 & & \\
\hline 1. Questions about the products cannot be answered before my purchase & & .659 & & \\
\hline 13. Delivery times are not convenient & & & .847 & \\
\hline 12. Delivery takes too long & & & .768 & \\
\hline 2. I don't want to pay extra fees, e.g. delivery charge & & & .596 & \\
\hline 10. I don't know how to shop online & & & & .826 \\
\hline 9. I don't know where to shop online & & & & .818 \\
\hline
\end{tabular}

Component one has five variables: question three, seven, fourteen, fifteen, and sixteen. This component relates to consumer dissatisfaction with the web as an effective medium for grocery shopping. In our sample, there was not a strong tendency towards this component (see Table 5b, Appendix A). 
Question one, four, and five are the key factors for component two which relates to the concern about gaining clear product information before purchasing. This was represented as a key issue; a distinct majority of our sample agreeing with all items (see Table 5b). In the open comments sections, many respondents chose to comment that the issue they were most concerned with was the need to examine food in person and pick up the freshest food (especially for short shelf life products) before purchasing. The concern is that the quality of products selected by the supermarket may not be what it should and lack of trust in this regard was emphasised. This all supports Morganosky and Cude's (2000) findings relating to inadequate product descriptions and Teo's (2002), Farag, Kriizek and Dijst (2006) and Gupta Handa and Gupta (2008) findings regarding the lack of ability to examine products.

The third component is derived from question two, twelve, and thirteen and relates to the problems with the delivery service in some way. The item regarding delivery charges elicited the strongest response $(74.7 \%$ agreed that this was a concern) which is consistent with Morganosky and Cude's (2000) findings. Interestingly, concerns over delivery convenience did not elicit a strong response (see Table 5b). In fact, some respondents chose to stress their satisfaction with the after-sale service and discussed the benefits of home delivery in the open comments sections.

Question nine and ten are the key factors for the fourth disadvantage of OGS and relate to problems of knowing how or where to shop for groceries online. This component reflects a theme of problems caused due to lack of familiarity with the web technology, the processes of OGS. Only a small minority declared this to be a problem however (see Table 5b).

\subsection{The factors that would increase the likelihood of shopping grocery online}

No components were identified. All items scored highly with the majority of respondents (over $60 \%$ agreement on all items).

The questions within this section encourage high acquiescence. Respondents are unlikely to reject improvements in any area, no matter how low the priority. Certain questions elicited higher than average agreement. The most important improvement to encourage more OGS was assurances that websites would treat consumers' personal information with strict confidentiality (88\%). Cheaper prices on the Web would also be a motivating factor (81.8\%). Despite no emphasis on delivery issues specifically in the problem section, $81.4 \%$ of respondents would be more likely to shop for groceries online if they had confidence in other aspects of after-sale service; returns procedures, for example.

\section{CONCLUSION}

The findings from our survey suggest a number of important factors which either promote or inhibit Internet users participating in OGS.

Few participants in our survey have recently engaged in OGS and most indicate that they still prefer the traditional means of shopping for groceries. This is despite the fact that the vast majority feel very confident using Internet technologies and have experience of shopping online in other retail contexts. The majority of our respondents were young women in full-time education with low income. However, although women in their 30's and 40's were a relatively small proportion of our sample, they engage in OGS more than other categories. This is consistent with previous on line grocery shopping research (Morganosky and Cude, 2000; Lokken, 2003; Rohm and Swaminathan, 2004) but does not shed any light on why this may be the case.

In order to explore the reasons for their grocery shopping choices, we identified common themes in behaviour and attitudes towards both traditional and online grocery shopping. The themes were identified in the light of previous work by Westbrook and Black (1985) and later of Rohm and Swaminathan (2004) in developing shopping typologies and where appropriate, similar labels are applied.

According to the relevant themes identified in terms of exploring both on and offline experiences, the majority of our respondents demonstrated behavior and attitudes that could be considered spontaneous, many tending to shop on impulse and without prior planning. Many respondents could also be categorized as functional shoppers, not concerned with the process and the experience of shopping but rather motivated by convenience and 
immediacy. Seeking variety of products and concern about optimal choice was not a behavioral type that was well represented in our survey. Factors related to convenience are predominantly highlighted as key to the motivation to adopt OGS and this is consistent with all previous research, across different products, retailers and markets. Convenience here is not only identified as the 'any time and any place' provision of internet shopping but also as the anticipated savings of time and effort. Interestingly, in contrast to previous research (e.g. Teo, 2002), there was no indication of disappointment in relation to these efficiency expectations. Neither delays when browsing on line nor waiting around for deliveries were highlighted as problematic concerns which is encouraging for online retailers to note.

Some of the established inhibiting factors, such as cost and speed of Internet access, finding browsing tiresome (Teo, 2002; Morganosky and Cude, 2000) were not viewed as problematic by our respondents. A very small minority were unsure about how or where to shop or expressed any dissatisfaction with the web itself in terms of convenience or efficiency. The advent of broadband, the continuing increase in domestic Internet access and improvements in web design and development may have removed these barriers to a large extent. If the views of our respondents were representative of the wider UK population, they present an optimistic picture to grocery retailers regarding consumer satisfaction in terms of site design, navigation and ease of use.

An important theme identified in the disadvantages of OGS was the concern about gaining clear product information before purchasing. There was strong agreement with all items linked by this theme; highlighting the worries regarding lack of ability to examine products. In some ways this appears inconsistent with the attitudes represented in other sections of the questionnaire which emphasise that convenience, functionality and spontaneity are rated above the need for choice and careful consideration of products. Only a small majority of people claimed they needed to examine products closely and very few rely on personal assistance when shopping in a bricks and mortar environment and yet these are issues that are considered important in the online environment. Some of the respondents' comments indicate that this may be due to a reluctance to trust shop personnel with the task of selecting appropriate and high quality merchandise. A reluctance to trust product marketing and selection implies there is a lack of confidence in the service provided by online retailers that is not an issue with bricks and mortar retailers.

Other common areas of concerns, in keeping with findings from previous research, were added costs (e.g. though added charges, non competitive prices), return and refund guarantees and, primarily, the need for confidentiality of personal information.

An underlying theme which seems to link many concerns is one of trust. These issues of trust relate, not only to online privacy issues, which has long been a priority concern in e-commerce research, but also to a lack of confidence regarding offline aspects of the service (choice of quality goods, delivery concerns, returns policies etc).

As our sample does include a high percentage of online shoppers, yet a low percentage of online grocery shoppers, we infer that some of the barriers discussed may be more pertinent to shopping for groceries online than to online shopping in some other contexts. We know from previous research (e.g. BBC News, 2004) that books and holidays are amongst the most popular items purchased online. It may be speculated that reliability is more of an issue for consumers planning to engage in regular and frequent purchasing of products (which is what grocery shopping entails), than for the occasional leisure purchase. Further research to explore consumer concerns, comparing different product and retailer types explicitly, may shed greater light on consumer motivations to shop or not to shop online.

\section{AUTHOR INFORMATION}

Dr. M. Saravanakumar holds three post graduate degrees in Business Administration, Commerce and Information Technology. Besides his brief corporate exposure, he has about 18 years of experience in teaching and research. He is a widely known academician and administrator of this region and has involved himself in the implementation of quality systems in reputed educational institutions. He has so far authored six books on Strategic Management, Financial Management, Disaster Management, Strategic Financial Management, Management of Financial Services and Management Accounting. He is the fellow member of Institute of Management Consultants of India. 
Currently, he is the Dean of -Academic Campus of Anna University of Technology Coimbatore in addition to Director i/c of Directorate of Online and Distance Education. E-mail: dr.k.k.ramachandran@ gmail.com

K. K. Karthick, Director, PMR Institute of Management, Chennai, India. E-mail: Karthick.hr@gmail.com

M. Saravana Kumar, Anna University, Coimbatore, India.

\section{REFERENCES}

1. Alba, J., et al., (1997). Interactive home shopping: consumer, retailer, and manufacturer incentives to participate in electronic marketplaces. Journal of Marketing, 61 (July), 38-53.

2. $\quad$ Armitt, C., (2004). Women and over-55s take lead in online shopping. New Media Age, 19 February, p.10.

3. Baltas, G., and Papaptathopoulou P., (2003). Shopper characteristics, product and store choice criteria: a survey in the Greek grocery sector. International Journal of Retail \& Distribution Management, 31 (10), 498-507.

4. Barlow, A. K. J., Siddiqui, N. Q., and Mannion, M., (2004). Developments in information and communication technologies for retail marketing channels. International Journal of Retail \& Distribution Management, 32 (3), 157-163.

5. $\quad B B C N E W S,(2002)$. Women lead in online shopping [online]. London: BBC News Website. Available at: <http://news.bbc.co.uk/1/hi/business/2444679.stm> [Accessed 18 May 05].

6. $\quad B B C N E W S$, (2004). Internet sales growing strongly [online]. London: BBC News Website. Available at: <http://news.bbc.co.uk/1/hi/business/4032809.stm> [Accessed $11 \mathrm{Feb} 05]$.

7. $\quad B B C$ NEWS (2009) Online shopping ahead $13 \%$ on 2008

8. Belenger, D. E., and Korgaonkar, P. K., (1980). Profiling the recreational shopper. Journal of Retailing, 56 (Fall), 77-91.

9. Blake, B. F., Neuendorf, K. A., and Valdisseri, C. M. V., (2003). Innovativeness and variety of Internet shopping. Internet Research: Electronic Networking Applications and Policy, 13 (3), 156-169.

10. Blaxter, L., Hughes, C., and Tight, M. (1996). How to research. Open University Press.

11. Bryman, A., and Bell, E. (2003). Business research methods. Oxford University Press.

12. Burnett, J. J., and McCollough, M., (1994). Assessing the characteristics of the non-store shopper. International Review of Retail, Distribution Consumer Research, 4 (4), 443-463.

13. Burns (2005). Online shopping statistics. Available at: http://www.clickz.html [Accessed 11 Sept 05].

14. ByrneE, D., (2002). Interpreting quantitative data. London: Sage Publications.

15. Casabayo, M., Agell, N., and Agudo, J. C., (2000). Using AI techniques in the grocery industry: identifying the customers most likely to defect. International Review of Retail, Distribution and Consumer Research, 14 (3), 295-308.

16. Childers, et al., (2001). Hedonic and utilitarian motivations for online retail shopping behavior. Journal of Retailing, 77 (2001), 511-535.

17. Clark, M., Riley, M., Wood, R. C., and Wilkie, E. (1998). Researching and writing dissertations in hospitality and tourism. London: International Thomson Business Press.

18. DTI, (2000). The UK is a globe leader in online trading [online]. London: Department of Trade and Industry. Available at: <http://www.dti.gov.uk/industries/ecommunications/online trading statistics.html> [Accessed $11 \mathrm{Feb} 05]$.

19. DTI, (2005). EBusiness [online]. London: Department of Trade and Industry. Available at: $<$ http://www.dti.gov.uk/industries/ecommunications/ebusiness.html > [Accessed $11 \mathrm{Feb} 05$ ].

20. Engel, J. F., Blackwell, R. D., and Miniard, P. W., (1995). Consumer behaviour. $8^{\text {th }}$ ed. Fort Worth: Dryden.

21. Farag, S. , Krizek, K. and Dijst, M. (2006) E-Shopping and its Relationship with In-Store Shopping: Empirical Evidence from the Netherlands and the USA. Transport Reviews, Vol. 26, Issue 1

22. Fraley, R. C., (2004). How to conduct behavioral research over the Internet: a beginner's guide to HTML and CGI/Perl. New York: The Guilford Press.

23. Gehrt, K. C., and Yan, R., (2004). Situational, consumer, and retailer factors affecting Internet, catalog, and store shopping. International Journal of Retail \& Distribution Management, 32 (1), 5-18. 
24. George, J.F., (2004). The theory of planned behaviour and Internet purchasing. Internet Research, 14 (3), 198-212.

25. Gomez INC., (2001). Key grocery shopping trends in online grocery buying study. Primedia Company. Available at: $<$ http://retailindustry.about.com/library/bl/bl_gomez0322.htm> [Accessed Oct. 2004].

26. Gupta, N. Handa, M. and Gupta, B (2008) Young Adults of India Online Surfers or Online Shoppers. Journal of Internet Commerce, Vol. 7 Issue 4.

27. Hair, J. F., et al., (1998). Multivariate data analysis. $5^{\text {th }}$ edition. New Jersey: Prentice-Hall, Inc.

28. Hansen, T., Jensen, J. M. and Solgaard, H. S., (2004). Predicting online grocery buying intention: a comparison of the theory of reasoned action and the theory of planned behavior. International Journal of Information Management, 24 (2004), 539-550.

29. Joia, L. A., and Sanz, P., (2005). The hidden value of sporadic customers in e-retailing: an empirical investigation. Internet Research, 15 (1), 7-20.

30. Konradt, U., et al., (2003). Usability in online shops: scale construction, validation and the influence on the buyers' intention and decision. Behaviour \& Information Technology, 22 (3), 165-174.

31. Lokken, S. L., et al., (2003). Comparing online and non-online shoppers. International Journal of Consumer Studies, 27 (2 March), 126-133.

32. Martin, S. Camareor, C. Hernandez, C,and Valla, L. (2009) Risk, Drivers and Impediments to online Shopping in Spain and Japan. Journal of Euromarketing, Vol. 18, Issue 1

33. Morganovsky, M. A., and Cude, B. J., (2000). Consumer response to online grocery shopping. International Journal of Retail \& Distribution Management, 28 (1), 17-26.

34. Park, C., and Kim, Y., (2003). Identifying key factors affecting consumer purchase behavior in an online shopping context. International Journal of Retail \& Distribution Management, 31 (1), 16-29.

35. Raijas, A., and Tuunainen, V. K., (2001). Critical factors in electronic grocery shopping. The International Review of Retail, Distribution and Consumer Research, 11 (3), 255-265.

36. Ranchhod, A. and Zhou, F., (2001). Comparing respondents of e-mail and mail surveys: understanding the implications of technology. Marketing Intelligence \& Planning, 19 (4), 254-262.

37. Riley, M., et al., (2000). Researching and writing dissertations in business and management. London: Thomson Learning.

38. Rohm, A. J., and Swaminathan, V., (2004). A typology of online shoppers based on shopping motivations. Journal of Business Research, 57 (2004), 748-757.

39. Rowley, J., (1996). Retailing and shopping on the Internet. International Journal of Retail \& Distribution Management, 24 (3), 26-37.

40. Rucai, L (2009) Online Shopping Business Develops by Leaps and Bounds. China Today, Vol. 58 Issue 5

41. Seager, A., (2005). Retail festive slump is worst for 10 years [online]. London: Guardian Newspapers Limited. Available at: <http://www.guardian.co.uk/business/story/0,3604,1387392,00.html > [Accessed 11 Feb 05].

42. Teo, T. S. H., (2002). Attitudes toward online shopping and the Internet. Behaviour \& Information Technology, 21 (4), 259-271.

43. Teo, T. S. H., (2006) To buy or not to buy online: adopters and non-adopters of online shopping in Singapore. Behaviour and Information Technology, Vol. 25, No. 6

44. The Office For National Statistics, 2002. 2001 online trading by UK business [online]. London: National Statistics. Available at: <http://www.statistics.gov.uk/pdfdir/ecom1002.pdf> [Accessed $11 \mathrm{Feb}$ 05].

45. The Office For National Statistics, 2009. Expenditure Highlights London: National Statistics. Available at: < http://www.statistics.gov.uk/CCI/nugget.asp?ID=1752\&Pos=\&ColRank=2\&Rank=224>

46. Weltevreden, J. and Van Rietbergen, T. (2009) The implications of e-shopping for in-store shopping at various shopping locations in the Netherlands. Environment and Planning, Vol. 36, Issue 2

47. Westbrook, R. A., and Black, W. C., (1985). A motivation-based shopper typology. Journal of Retailing, $61(1), 78-103$.

48. Yang, B., and Lester, D., (2004). Attitudes toward buying online. Cyber Psychology \& Behavior, 7 (1), 91. 


\section{APPENDIX A}

Frequency Reports: questions highlighted in Principal Component Analysis

Table 3b: Consumers' experience and attitudes toward traditional (offline) grocery shopping

\begin{tabular}{|c|c|c|c|}
\hline $\begin{array}{l}\text { Consumers experiences and attitudes toward online grocery shopping } \\
\text { (261 respondents) }\end{array}$ & $\begin{array}{l}\text { Strongly disagree } \\
\text { and disagree }(\%)\end{array}$ & Neutral & $\begin{array}{l}\text { Strongly agree } \\
\text { and agree }(\%)\end{array}$ \\
\hline 1. I often buy things that I didn't plan to buy during my grocery shopping & 15.8 & 11.7 & 72.5 \\
\hline 9. I enjoy grocery shopping & 24.0 & 41.1 & 35.0 \\
\hline 10. I go grocery shopping even when I am unsure what I need & 34.5 & 21.5 & 43.9 \\
\hline 6. I go to different shops to compare prices and products & 37.9 & 23.3 & 38.8 \\
\hline 7. I often ask shop assistants to give me suitable advice & 60.3 & 25.1 & 14.6 \\
\hline 8. I like to feel and touch the products before I purchase them & 20.6 & 24.3 & 55.0 \\
\hline 2. It's important for me to get the goods straight away after my shopping & 7.3 & 26.4 & 66.2 \\
\hline 3. I go to the nearest shops for my weekly grocery shopping & 32.4 & 17.4 & 50.2 \\
\hline
\end{tabular}

Table 4b: Reasons and motivations for purchasing grocery online

\begin{tabular}{|c|c|c|c|}
\hline Grocery shopping on-line enables me to: (93 respondents) & $\begin{array}{l}\text { Strongly disagree } \\
\text { and disagree }(\%)\end{array}$ & Neutral & $\begin{array}{l}\text { Strongly agree } \\
\text { and agree }(\%)\end{array}$ \\
\hline 5. ... choose from a wider selection & 41.5 & 30.3 & 28.1 \\
\hline 6. ... have the latest products and services & 26.7 & 46.7 & 26.6 \\
\hline 4. ... be on the leading edge of technology & 24.4 & 46.7 & 28.9 \\
\hline 3. ... get better prices & 32.6 & 37.1 & 30.3 \\
\hline 8. ... save time & 16.8 & 23.6 & 59.5 \\
\hline 11.... make less effort in doing shopping & 25.0 & 27.3 & 47.8 \\
\hline 2. ... order groceries from distant places & 17.7 & 28.9 & 53.3 \\
\hline 1. ... buy groceries at any time & 18.4 & 25.0 & 56.5 \\
\hline 7. ... do shopping anywhere as far as I can access the Internet & 11.2 & 23.6 & 65.1 \\
\hline
\end{tabular}

Table 5b: Disadvantages of OGS

\begin{tabular}{|c|c|c|c|}
\hline $\begin{array}{c}\text { Problems and disadvantages of online grocery } \\
\text { shopping perceived by consumers: }(214 \text { respondents })\end{array}$ & $\begin{array}{l}\text { Strongly disagree } \\
\text { and disagree }(\%)\end{array}$ & Neutral & $\begin{array}{l}\text { Strongly agree } \\
\text { and agree }(\%)\end{array}$ \\
\hline 16. The products purchased on-line are not as good as described on the Web & 24.0 & 56.0 & 20.1 \\
\hline 14. I don't have time to search information from the Web & 46.4 & 32.2 & 21.3 \\
\hline 7. It takes too long to complete the purchase & 22.7 & 40.3 & 37.0 \\
\hline 15. I can't buy the range of products I want on-line & 28.1 & 44.3 & 27.6 \\
\hline 3. The sites are not easy to look through & 20.4 & 41.2 & 38.4 \\
\hline 5. The products are not well described & 12.5 & 50.2 & 37.4 \\
\hline 4. I cannot try out the products & 7.1 & 29.2 & 63.7 \\
\hline 1. My questions about the products cannot be answered before my purchase & 10.8 & 22.5 & 66.7 \\
\hline 13. Delivery times are not convenient & 24.6 & 38.4 & 37.0 \\
\hline 12. Delivery takes too long & 23.9 & 45.7 & 30.5 \\
\hline 2. I don't want to pay extra fees, e.g. delivery charge & 8.4 & 16.9 & 74.7 \\
\hline 10. I don't know how to shop on-line & 73.8 & 15.2 & 10.9 \\
\hline 9. I don't know where to shop on-line & 67.7 & 16.6 & 15.6 \\
\hline
\end{tabular}




\section{NOTES}

